\title{
Diagnostic accuracy of endoscopy for the detection of isthmuses of mandibular molar teeth using micro-CT as reference
}

\section{Purpose}

The aim of this study was to evaluate the efficacy of endoscopic visualisation to detect the presence and type of isthmuses within the mesial root canals of mandibular first molar teeth compared with micro-computed tomography (micro$\mathrm{CT}$ ) images as reference.

\section{Materials and Methods}

Thirty-two mesial roots of mandibular first molars presenting isthmuses were selected based on micro-CT scans. In all, 12 type I and 20 band-shaped isthmuses were collected. The specimens were mounted in the posterior socket of dental phantom manikin for endoscopic visualisation. The ability of endoscopes to visualize the presence of isthmuses and distinguish the type of isthmuses was compared. Micro-CT images of the specimens were used as references. Data were analyzed using Fisher's exact tests.

\section{Results}

Sensitivity of endoscope to detect isthmuses were also calculated for each isthmus type. In $37.5 \%$ of the samples, isthmus presence was correctly diagnosed via orthograde endoscopic visualization. Type I istmuses were significantly more detected than band-shaped isthmuses $(P<0.05)$. Endoscope showed higher sensitivity to detect type I isthmus than band-shaped isthmus.

\section{Conclusion}

The endodontic endoscope could detect type I isthmuses more accurately than band- shaped isthmuses.

Keywords: Isthmus, Micro-computed tomography, Endoscopic visualization, Root canal anatomy

\section{Introduction}

The success of root canal treatment relies on a complete disinfection, shaping and three-dimensional filling of root canal system. Failure to understand root canal configurations along with their irregularities may result in treatment failure. Therefore, root canal anatomy have been extensively investigated and mesial roots of mandibular molars have been associated with frequent anatomical variations such as isthmuses, fins, branchings, dividing, and re-joining of root canals at different levels (1). Most commonly detected root canal configuration is Vertucci type IV, which describes two independent canals, followed by Vertucci type II (merging of two canals in a single terminus) and Vertucci type VI (merging and re-dividing of two canals) $(2,3)$. However, mesial roots could also show very complex unclassified canal configurations (1).

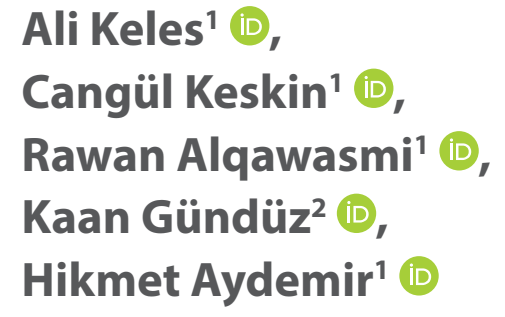

ORCID IDs of the authors: A.K. 0000-0003-2835-767X C.K. 0000-0001-8990-4847; R.A. 0000-0002-1544-6844; K.G. 0000-0002-0464-1978; H.A. 0000-0001-5750-8831

${ }^{1}$ Department of Endodontics, Faculty of Dentistry, Ondokuz Mayıs University, Samsun, Turkey

${ }^{2}$ Department of Dentomaxillofacial Radiology, Faculty of Dentistry, Ondokuz Mayıs University, Samsun, Turkey

Corresponding Author: Cangül Keskin E-mail: canglkarabulut@gmail.com

Received: 5 June, 2020 Revised: 20 July, 2020 Accepted: 2 November, 2020 DOI: $10.26650 /$ eor.20210065 
When two canals are present in a single root, isthmus could be detected. An isthmus is a narrow, ribbon-shaped structure with a long oval cross section that forms as the result of merging of the two root canals widening in the buccolingual direction. Isthmus could occur in any root, which can increase its incidence up to $83 \%$ in mesial roots of mandibular molar teeth (4-6). Isthmus is most commonly detected in 3-5 $\mathrm{mm}$ from the apical foramen (5). Isthmuses have been classified by Fan et al. according to their shapes as sheet, separate, mix and cannular connections (6). Type I isthmus is described as a continuous narrow sheet-like connection between canals (6). Isthmuses could also present high variability as canal configurations do. Band-shaped isthmus is recently described as a band-shaped oval connection formed between 2 merging and then dividing root canals having its own isthmus roof and floor (3). The complexity of high variability of isthmuses present challenge for proper disinfection, cleaning and obturation of the root canal system (7).

Micro-CT emerged as the most accurate technique to reveal the internal anatomy of different root canal system due to the production of high-resolution images $(8,9)$. Micro-CT is considered a gold standard reference method for in vitro evaluation of the efficacy of root canal anatomy visualization techniques in (8). The in vivo use of micro-CT is not suitable because of high radiation dose. On the other hand, cone-beam computed tomography (CBCT) provides limited information when it comes to the reflect actual anatomy of canal system (8). A previous study used micro-CT scanning as a reference by which to test the accuracy of CBCT and

reported that $C B C T$ was not sufficient to reveal the actual root canal configurations and fine structures of root canal anatomy compared to micro-CT (8).

Magnification devices such as dental operating microscope (DOM) are valuable diagnostic and operative tools for the detection of root canal orifices and accessory canals, vertical cracks, visualization of broken instruments, or residual root canal filling materials within root canals $(10,11)$. The efficacy of DOM to visualize the components of root canal configuration depends mainly on the operator experience (12). The use of DOM requires a preparation and training prior to effective use particularly in mandibular molars, because adjustment of microscope light to reach lateral root canal walls is limited by the surrounding tissues, walls of the access cavity and inclination of root canals, which is commonly detected in mesial root canals of mandibular molars with isthmuses (13).

Endoscopic visualization is a safe magnification and examination technique that does not involve $\mathrm{X}$-ray radiation. Endoscopes have been developed for in vivo use to visualize root canal configurations and detect variations $(13,14)$. A recent study showed the ability of root canal endoscope to detect branching points of anatomosis from main root canals (15). However, to authors' knowledge, there is few data in literature about orthograde detection of isthmuses by endoscope during nonsurgical root canal treatment. This study evaluates the effectiveness of orthograde endoscopic visualization to detect the presence and type of the isthmuses by using micro-computed tomography (micro-CT) images as reference. The null hypotheses were those:

1. The root canal endoscope would detect the presence of isthmuses with $>90 \%$ sensitivity.

2. The root canal endoscope would identify isthmus type equally in Type I and band-shaped isthmuses.

\section{Materials and Methods}

\section{Sample size calculation}

Total sample size for the study was calculated following the effect size calculation of the results of a previous in vitro study (13). Following the X2 family and goodness of fit contingency tables with an alpha-type error by 0.05 and power beta of 0.80 (G*Power 3.1 for Macintosh; Heinrich Heine, Universitat Dusseldorf, Dusseldorf, Germany) a total of 30 samples was indicated as the minimum ideal size.

\section{Micro-CT scanning and specimen selection}

The mesial roots of 269 mandibular molar teeth extracted for reasons unrelated to this study were scanned using a micro-CT system (SkyScan 1172; Bruker-microCT, Kontich, Belgium) with parameters of $100 \mathrm{kV}$ and $100 \mu \mathrm{A}$. Slices presenting $2000 \times 1330$ pixel resolution with $10 \mu \mathrm{m}$ pixel size were obtained from each root using an $11 \mathrm{MP}$ camera. Data were reconstructed using NRecon software (v.1.6.4, Bruker-microCT) with a beam-hardening correction of $45 \%$, smoothing of two, and an attenuation coefficient range of 0-0.06. CTAn and DataViewer (v.1.5, Bruker-microCT) software were used to reveal the root canal configuration of each root. Patient gender and age were unknown. In all, 32 micro-CT datasets of 32 specimens having isthmus were selected and further analyzed. Twelve specimens showed a type I isthmuses, while 20 specimens had band-shaped isthmuses.

\section{Endoscopic visualization}

Prior to endoscopic visualization, the root canals were chemomechanically prepared. Working length (WL) was established by inserting a size $8 \mathrm{~K}$-file (Dentsply Sirona, Ballaigues, Switzerland) through the apical foramen until its tip was visible from apical foramen and recorded as $1.0 \mathrm{~mm}$ shorter than the measured length. Apical patency was confirmed by inserting a size $10 \mathrm{~K}$-file $0.5 \mathrm{~mm}$ through the apical foramen. The root canals were prepared using Reciproc Blue R25 instruments (VDW GmbH, Munich, Germany). The instrument was introduced into the canal until resistance was felt and operated in "Reciproc All" mode using VDW silver endomotor (VDW, Munich, Germany). The instrument was used gently in apical direction using pecking motions with amplitude of $3 \mathrm{~mm}$. Following 3 pecking motions the instrument was removed from the canal and cleaned. Each time the instrument was removed, the root canals were irrigated with $2.5 \mathrm{~mL}$ of $5.25 \% \mathrm{NaOCl}$ using a $30-\mathrm{G}$ closed-end tip needle adapted to a plastic syringe placed $1 \mathrm{~mm}$ short of the working length. After preparation, the root canals received a final irrigation of $2.5 \mathrm{~mL}$ of $17 \%$ EDTA and sterile saline solution and were dried with paper points. A single experienced endodontist performed all root canal preparation procedures.

Following preparation, the specimens were placed in the posterior socket of dental phantom manikin (Frasaco $\mathrm{GmbH}$, Tettnang, Germany) to simulate clinical conditions as closely as possible (16). The endoscopic device included a 15-inch liquid crystal display thin film transistor monitor with LED backlight with $1024 \times 768$ resolution (Karl Storz GmbH \& Co. 
KG, Tuttlingen, Germany), camera head (Karl

Storz, Germany) and a root canal telescope with $0.5 \mathrm{~mm}$ outer diameter and 0 degree viewing angle (Karl Storz, Germany). Two independent evaluators performed analysis of endoscopic visualization. They had the information of presence of isthmus. But, firstly, the details of isthmuses such as type and position were not given the evaluators. The root canal endoscope was inserted into the mesiobuccal and mesiolingual canals, and internal anatomies of root canals were visualized. The presence or absence of isthmus was recorded as 'detected / undetected'. Also, in the case of detecting isthmus, the type of isthmus that could be detected recorded as 'Type I / Bandshaped'. After the scoring procedures, the evaluators were given the reconstructed micro-CT images to examine the three-dimensional appearance of specimens. The accuracy of endoscopy to confirm the type of the Type I or band- shaped isthmuses was evaluated as "correct" and "incorrect". Only the 'correct' marks were used in statistical analysis.

\section{Statistical analysis}

Data obtained from endoscopic examination were statistically analyzed by Fisher's exact tests regarding the ability to detect the presence of isthmus and distinguish the isthmus type. Inter-examiner reliabilities for each assessment were verified by Kappa test. Statistical analyses were performed by SPSS software (SPSS, Inc., Chicago, IL, USA), with a level of significance set at $5 \%$.

Sensitivity and positive predictive values were also calculated using a calculator software (MedCalc, Mariakerke, Belgium). Sensitivity was defined as the proportion of the isthmuses correctly diagnosed by endoscope (true positive), while positive predictive value was the ratio of true positive to combined true and false positive. No negative specimen was evident within the study plan; therefore, specificity or negative predictive value were not calculated.

\section{Results}

Both examiners reached the same results (Kappa value of 1.0). Endoscopic visualization could detect only 12 of 32 samples (37.5\%). In $62.5 \%$ sample, the presence of isthmus could not be detected by orthograde endoscopic visualization. Table 1 presents the number of isthmus types distinguished by the endoscopic examinations. According the results of this study, Type I istmuses were significantly more detected than band-shaped isthmuses $(P<0.05)$.

Sensitivity of endoscope to diagnose Type I isthmuses were higher than that of band-shaped isthmuses. Positive predictive values were $100 \%$ for both type of isthmuses.

Table 1. Number (percentage) of the correctly diagnosed isthmus types and sensitivity values (95\% confidence intervals) for endoscope

\begin{tabular}{lcc}
$\begin{array}{l}\text { Isthmus type/ } \\
\text { Estimation }\end{array}$ & $\begin{array}{c}\text { Correct endoscopic } \\
\text { examination }\end{array}$ & Sensitivity \\
\hline Type I & $7(58.3 \%) a$ & $58.3 \%(27.6-84.8 \%)$ \\
\hline Band-shaped & $5(25.0 \%) b$ & $20.0 \%(6.8-40.7 \%)$
\end{tabular}

Different superscript letters in the same column mean significant differences between isthmus types $(P<0.05)$.
Figure 1 shows representative images of the isthmuses acquired from endoscopic visualization.
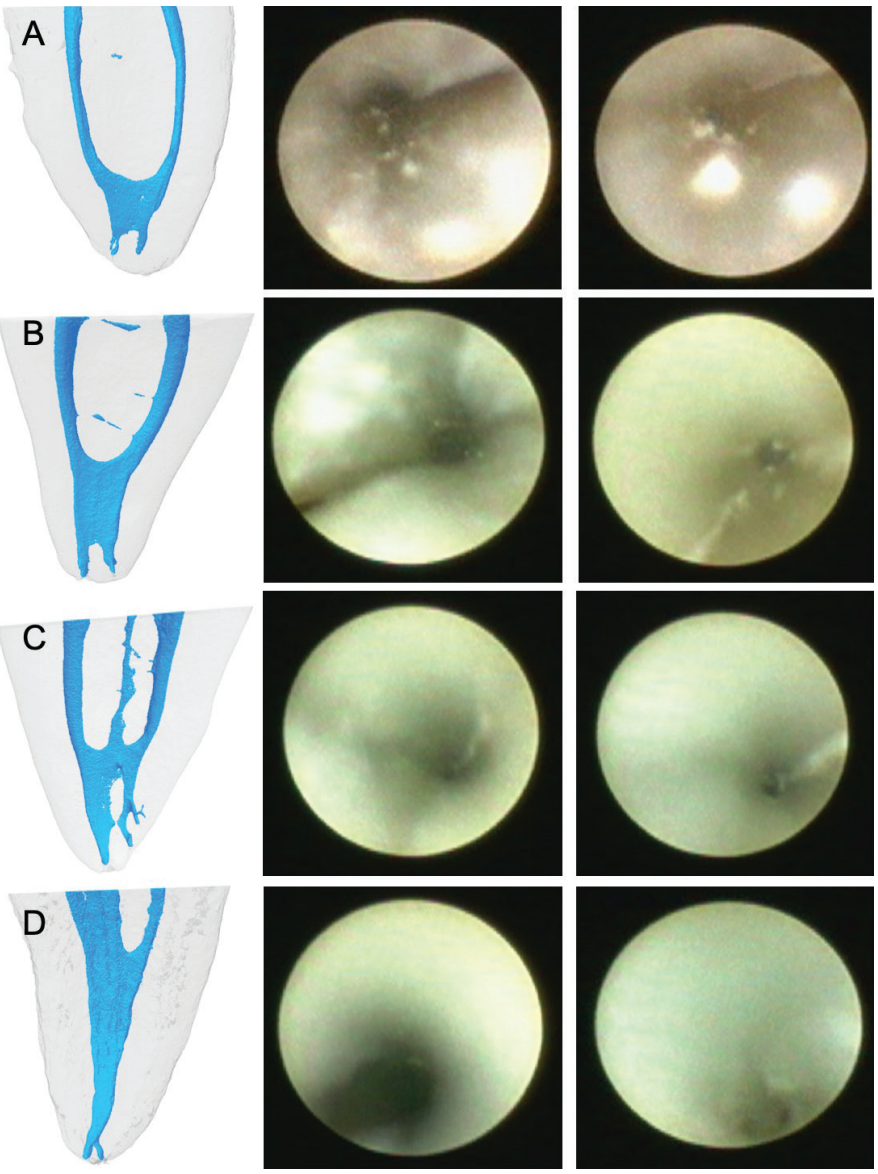

Figure 1. Band-shaped isthmuses could be detected by endoscopic visualization in ' $A$ ' and ' $B$.' The third column depicts the isthmus floor structures. Band-shaped isthmus type could not be distinguished in ' $C$ '. Despite the visualization of accumulated debris throughout the root canal it was not considered as isthmus. Type I isthmus was detected in 'D.' Apical branching of root canal in this sample could be detected via endoscopy in the third column.

\section{Discussion}

Endoscopic visualization is a safe and practical technique that does not involve radiation and has a potential for the development of novel techniques for the direct visualization of internal root canal anatomy without harming the patient. Because of bundled fibers, the endoscopic system can produce low-contrast images, which have poor resolution in diagnosis. Recently, many researchs have been aimed to improve the obtained images by enhancing hardware and software (17) or test the endoscope to detect the limitations in root canal (14).

The endoscope allows chairside use for clinicians to observe root canal anatomy at various angles without losing field depth and focus and provides magnified images of operation field to be recorded and archieved (14). In the present study, endoscopic evaluation of different isthmus types provided lower sensitivity values than hypostetized, which led to the rejection of first hypothesis. Endoscope could also detect type I isthmuses more accurately than band-shaped isthmuses leading to the rejection of second hypothesis. 
Orthograde use of endoscopes in nonsurgical endodontics is relatively novel. There have been a few studies regarding its possible indications; however, advantages and limitations of this technique have not yet been studied $(13-15,18,19)$. In this study, special care was given to simulate clinical conditions as best as possible by using dental fantom manikin for endoscopic visualisation. The root canal telescope of the endoscopic unit has $0.5 \mathrm{~mm}$ diameter and limited flexibility, so it was not possible to use endoscopic units in unprepared and uncleaned root canals, which might be a limitation of this technique. Following chemomechanical root canal preparation, endoscopic visualization revealed detailed images regarding the presence and the type of the isthmus (Fig. 1).

Endoscopic telescopes have a stainless steel tip that shows a semirigid structure for the protection of fiber cables within it. The visual angle provided by this semirigid tip is not clear. It was previously mentioned that the apical part of $46.6 \%$ of samples could be seen by endoscopic visualisation (13). In this study, apical parts of all samples could be seen. But, only $37.5 \%$ isthmuses could be detected. According to the results of this study, endoscopic visualization was able to detect significantly greater Type I isthmus than band-shaped isthmus. When inside a mesial root canal

with Vertucci type II canal configuration, the endoscopic telescope is guided to the merging area of two mesial canals by the root canal walls, and the tip of the telescope is positioned in front of the isthmus area rather than laterally. This tip direction faced directly to the isthmus area could make the Type I isthmus more easily visualized by endoscopy. Band-shaped isthmuses showed wide major diameter values at the floor of the isthmus (3). This wide major diameter might reflect that two mesial root canals do not predispose towards each other as the Type I isthmuses do. Thus, band-shaped isthmuses are positioned laterally to the endoscopic tip inserted to the relatively straight root canals in corono-apical direction. The lower detection rate of bandshaped isthmuses compared to Type I isthmuses migth be attributable to that reason. Moreover, in some specimens that were defined as having isthmus clearly via endoscopy, the isthmus floor or the presence of two independent apical root canals could not be detected. In this study, it was clear that endoscopic visualisation technology also lacks performing parametrical measurements of isthmus length or major diameter.

Micro-CT technology produces high-resolution images and allows qualitative and quantitative analyses of internal root canal anatomy without harming the specimens irreversibly (6). Due to its accuracy and protectivity of the specimens, micro-CT images can be used to evaluate the efficacy of other visualization and imaging techniques as reference data (8, $20,21)$. The use of 3D images obtained via micro-CT for the testing of endoscopes is important for the reliability of the results. A similar methodology was applied in this study to test the efficacy of endoscopic visualization and CBCT scanning images for the detection of isthmus presence and type. Ordinola-Zapata et al. reported that CBCT accurately diagnosed a Vertucci type II canal configuration, while it failed to diagnose configurations other than type I and II (8). Endoscopic evaluation may help clinicians to consider other canal configuration variations during examination of an isthmus floor indicating division of canals near apical third.
Isthmus requires special consideration in all procedures of root canal treatment, however accurate identification of an isthmus and its type, is very challenging clinically $(20,21)$. Particulary when an isthmus is located in apical third, it is nearly impossible to diagnose by visual inspection under DOM or dental loupe without CBCT, which is not a part of routine treatment due to radiation dose (22). On the other hand, even CBCT could fail to present isthmus type accurately especially in

apical third despite high resolution, leading to underdiagnosis of a complex apical anatomy $(20,21)$. Endoscopy provides a X-ray free imaging technique, however this technique should be developed to increase its efficacy to visualize root canal anatomy. Isthmus incidence has also been reported to be influenced by patient age; isthmuses are more prevalant in younger patients $(23,24)$. All specimens included to the present study had either type I or band-shaped isthmus despite the lack of

information regarding patient age, which may present a limitation.

\section{Conclusion}

Overall, the findings of the present study showed that detectability of isthmuses by endoscopy has $37.5 \%$ rate. Type I isthmuses were more detectable via endoscopic visualization than band-shaped isthmuses due to their less intricate anatomy. Further studies are warranted for the development of the root canal telescope and endoscopic unit to achieve more detailed and direct visualization of internal root canal anatomy without harming the patient.

Türkçe Özet: Referans OlarakMikro-BT KullanılarakAlt Çene MolarDişlerdeki Isthmusların Tespiti için Endoskopinin Tanısal Doğruluğu. Amaç:Bu çalışmanın amacı, mikro bilgisayarlı tomografi (mikro-BT) görüntülerini karşılaştırma amaçlı kullanarak, endoskopların mandibular birinci molar dişlerin meziyal kök kanallarındaki isthmusların varlığını ve tipini saptamadaki etkinliğini değerlendirmektir. Gereç ve Yöntem: Mikro-BT taramalarına göre ishtmus içeren 32 mandibular birinci azı dişi toplandı. Toplamda, 12 tip I ve 20 bant şekilli isthmus elde edildi. Örnekler, endoskopik görüntüleme için dental fantom mankenin alt çene posteior soketine yerleştirildi. Endoskopların isthmus varlığını görüntüleme ve isthmus tipini ayırt edebilme becerileri karşılaştırıldı. Örneklerin mikroBT görüntüleri karşılaştırma için referans olarak kullanıldı. Veriler Fisher testi ile analiz edildi. Bulgular: Her isthmus tipi için endoskopun isthmusları saptama duyarlılığı da hesaplandı. Örneklerin\% 37.5'inde isthmus varlığı ortograd endoskopik görüntüleme ile doğru şekilde teşhis edildi. Tip I istmuslar bant şeklindeki isthmuslara göre anlamlı olarak daha fazla saptandı $(P<0.05)$. Endoskop tip I isthmusları saptamada bant şeklindeki isthmustan daha yüksek duyarlılık göstermiştir. Sonuç: Endodontik endoskop, tip I isthmusları bant şeklindeki isthmuslardan daha kesin olarak saptayabilir. Anahtar kelimeler: Istmus, mikro-bilgisayarlı tomografi, endoskopik görüntüleme, kök kanal anatomisi

Ethics Committee Approval: The local university ethical committee board approved the study protocol.

Informed Consent: Informed consent was obtained from each patient.

Peer-review: Externally peer-reviewed.

Author contributions: $\mathrm{AK}, \mathrm{CK}, \mathrm{RA}, \mathrm{KG}$ and $\mathrm{HA}$ designed the study. $\mathrm{AK}, \mathrm{CK}, \mathrm{RA}, \mathrm{KG}$ and $\mathrm{HA}$ participated in generating the data for the study $A K, C K, R A, K G$ and $H A$ participated in gathering the data for 
the study. AK, $C K, R A$, and $K G$ participated in the analysis of the data. $A K, C K$ and RA wrote the majority of the original draft of the paper. AK, CK and HA participated in writing the paper. All authors approved the final version of this paper.

Conflict of Interest: Authors declared no conflict of interest.

Financial Disclosure: This study was supported by the Scientific and Technological Research Council of Turkey-TUBITAK (grant no. 117S139).

\section{References}

1. Marceliano-Alves MF, Lima CO, Nayre-Bastos PM, Bruno AM, Vidaurre F, Coutinho TM, Fidel SR, Lopes RT. Mandibular mesial root canal morphology using micro-computed tomography in a Brazilian population. Aust Endod J 2019;45:51-6. [CrossRef]

2. Martins JNR, Marques D, Silva EJNL, Caramês J, Versiani MA. Prevalence studies on root canal anatomy using cone-beam computed tomographic imaging: a systematic review. J Endod 2019;45:372-86. [CrossRef]

3. Keleş A, Keskin C. A micro-computed tomographic study of band-shaped root canal isthmuses, having their floor in the apical third of mesial roots of mandibular first molars. Int Endod J 2018;51:240-6. [CrossRef]

4. Von Arx T. Frequency and type of canal isthmuses in first molars detected by endoscopic inspection during periradicular surgery. Int Endod J 2005;38:160- 8. [CrossRef]

5. Teixeira FB, Sano CL, Gomes BPFA, Zaia AA, Ferraz CCR, SouzaFilho FJ. A preliminary in vitro study of the incidence and position of the root canal isthmus in maxillary and mandibular first molars. Int Endod J 2003;36:276- 80. [CrossRef]

6. Fan B, Pan Y, Gao Y, Fang F, Wu Q, Gutmann JL. Three-dimensional morphologic analysis of isthmuses in the mesial roots of mandibular molars. J Endod 2010;36:1866-9. [CrossRef]

7. Siqueira JF, Alves FR, Versiani MA, Rocas IN, Almeida BM, Neves MA, Sousa-Neto MD. Correlative bacteriologic and microcomputed tomographic analysis of mandibular molar mesial canals prepared by Self-Adjusting File, Reciproc, and Twisted File systems. J Endod 2013;39:1044-50. [CrossRef]

8. Ordinola-Zapata R, Bramante C, Versiani M, Moldauer BI, Topham G, Gutmann JL, Nunez A, Duarte MA, Abella F. Comparative accuracy of the clearing technique, CBCT and Micro-CT methods in studying the mesial root canal configuration of mandibular first molars. Int Endod J 2017;50:90-6. [CrossRef]

9. Domark JD, Hatton JF, Benison RP, Hildebolt CF. An ex vivo comparison of digital radiography and cone-beam and micro computed tomography in the detection of the number of canals in the mesiobuccal roots of maxillary molars. J Endod 2013;39:901-5. [CrossRef]

10. Carr GB, Murgel CA The use of the operating microscope in endodontics. Dent Clin 2010;54:191-214. [CrossRef]
11. Mendes $A B$, Soares AJ, Martins JNR, Silva EJNL, Frozoni $M R$. Influence of access cavity design and use of operating microscope and ultrasonic troughing to detect middle mesial canals in mandibular first molars. Int Endod J 2020; doi:10.1111/ IEJ.13352. [CrossRef]

12. Khalighinejad N, Aminoshariae A, Kulild JC, Williams KA, Wang J, Mickel A. The effect of the dental operating microscope on the outcome of nonsurgical root canal treatment: a retrospective case-control study. J Endod 2017;43:728- 32. [CrossRef]

13. Engelke W, Leiva C, Wagner G, Beltrán V. In vitro visualization of human endodontic structures using different endoscope systems. Int J Clin Exp Med 2005;8:3234-40.

14. Moshonov J, Michaeli E, Nahlieli O. Endoscopic root canal treatment. Quintessence Int 2009;40:739-44.

15. Keleş A, Keskin C, Alqawasmi R, Aydemir H. Accuracy of an endoscope to detect root canal anastomoses in mandibular molar teeth: a comparative study with micro-computed tomography. Acta Odontol Scand 2020;6:1. [CrossRef]

16. Silva AA, Belladonna FG, Rover G, Lopes RT, Moreira EJL, DeDeus $G$, Silva EJNL. Does ultraconservative access effect the efficacy of root canal treatment and the fracture resistance of two-rooted maxillary premolars? Int Endod J 2020;53:265-75. [CrossRef]

17. Fujimoto $M$, Okuda M, Yoshii S, Ikezawa S, Toshitsugu U, Tassery H, Cuisinier F, Kitamura C. Endoscopic System Based on Intraoral Camera and Image Processing. IEEE Trans Biomed Eng 2019;66:1026-33. [CrossRef]

18. Bahcall JK, DiFiore PM, Poulakidas TK. An endoscopic technique for endodontic surgery. J Endod 1999;25:132-5. [CrossRef]

19. Detsch SG, Cunningham WT, Langloss JM. Endoscopy as an aid to endodontic diagnosis. J Endod 1979;5:60-2. [CrossRef]

20. Tolentino ES, Amoroso-Silva PA, Alcalde MP, Honorio HM, Iwaki LCV, Rubira-Bullen IRF, Hungaro-Duarte MA. Accuracy of high resolution small- volume cone-beam computed tomography in detecting complex anatomy of the apical isthmi: ex vivo analysis. J Endod 2018;44:1862-6. [CrossRef]

21. Tolentino ES, Amoroso-Silva PA, Alcalde MP, Honorio HM, Iwaki LCV, Rubira-Bullen IRF, Hungaro-Duarte MA. Limitation of diagnostic value of cone-beam CT in detecting apical root isthmuses. J Appl Oral Sci 2020;27;28:e20190168. [CrossRef]

22. Hu X, Huang Z, Huang Z, Lei L, Cui M, Zhang X. Presence of isthmi in mandibular mesial roots and associated factors: an in vivo analysis. Surg Radiol Anat 2019;41:815-22. [CrossRef]

23. Gani OA, Boiero CF, Correa C, Masin I, Machado R, Silva EJ, Vansan LP. Morphological changes related to age in mesial root canals of permanent mandibular first molars. Acta Odontol Latinoam 2014;27:105-9.

24. Estrela C, Rabelo LE, de Souza JB, Alencar AH, Estrela CR, Sousa Neto MD, Pecora JD. Frequency of root canal isthmi in human permanent teeth determined by cone-beam computed tomography. J Endod 2015;41:1535-9. [CrossRef] 